\title{
Assessing methods for the estimation of response times of stream discharge: the role of rainfall duration
}

\author{
Jaime G. Cuevas ${ }^{1,2^{*}}$, José L. Arumí ${ }^{3}$ José Dörner ${ }^{2,4}$ \\ ${ }^{1}$ Centro de Estudios Avanzados en Zonas Áridas (CEAZA), Av. Raúl Bitrán 1305, La Serena, Chile. \\ ${ }^{2}$ Centro de Investigación en Suelos Volcánicos (CISVo), Universidad Austral de Chile, Valdivia, Chile. \\ ${ }^{3}$ Facultad de Ingeniería Agrícola, Departamento de Recursos Hídricos, Centro CRHIAM, Universidad de Concepción, Chillán, Chile. \\ ${ }^{4}$ Instituto de Ingeniería Agraria y Suelos, Universidad Austral de Chile, Valdivia, Chile. \\ * Corresponding author. Tel.: +56 51 2204378. E-mail: jxcuevas@ceaza.cl
}

\begin{abstract}
Lagtimes and times of concentration are frequently determined parameters in hydrological design and greatly aid in understanding natural watershed dynamics. In unmonitored catchments, they are usually calculated using empirical or semiempirical equations developed in other studies, without critically considering where those equations were obtained and what basic assumptions they entailed. In this study, we determined the lagtimes (LT) between the middle point of rainfall events and the discharge peaks in a watershed characterized by volcanic soils and swamp forests in southern Chile. Our results were compared with calculations from 24 equations found in the literature. The mean LT for 100 episodes was 20 hours (ranging between 0.6-58.5 hours). Most formulae that only included physiographic predictors severely underestimated the mean LT, while those including the rainfall intensity or stream velocity showed better agreement with the average value. The duration of the rainfall events related significantly and positively with LTs. Thus, we accounted for varying LTs within the same watershed by including the rainfall duration in the equations that showed the best results, consequently improving our predictions. Izzard and velocity methods are recommended, and we suggest that lagtimes and times of concentration must be locally determined with hyetograph-hydrograph analyses, in addition to explicitly considering precipitation patterns.
\end{abstract}

Keywords: Empirical equations; Lagtimes; Semiempirical equations; Streamflow; Times of concentration.

\section{INTRODUCTION}

Streamflow does not respond instantaneously to rainfall; there is a delay between rain and discharge peaks (McCuen, 2009). This gave origin to the concepts of lagtimes (LT) and times of concentration $(\mathrm{Tc})$, which are frequently determined to understand natural watershed dynamics and in hydrological design (de Almeida et al., 2014; Sharifi and Hosseini, 2011). These parameters are essential to accurately calculate the maximum discharge, which is necessary for the proper design of culverts, bridges and many other hydraulic works (Sharifi and Hosseini, 2011).

The most reliable way to determine both LT and Tc is the graphical study of hyetographs and hydrographs for a period of time long enough to determine the natural variability of precipitation and streamflow, and therefore the periods of return of large storms and floods (Bentancor et al., 2014; de Almeida et al., 2017). However, in many cases no background information is available regarding the behavior of a given watershed before the construction of a hydraulic work. Thus, in unmonitored catchments both Tc and LT are usually calculated from empirical, semiempirical, or physically based equations developed in previous studies. Empirical formulae are based on watershed physiographic characteristics, such as terrain slope, channel slope, watershed area, channel length, etc. (e.g., Giandotti, 1940; Kirpich, 1940). These formulae do not consider the temporal and spatial variability of factors that can affect response times. Conversely, semiempirical equations also consider other variables, such as the roughness coefficient or the curve number associated with, for example, the vegetation type and density, which can vary spatially and temporally (Mata-Lima et al., 2007). The usual approach in both empirical and semiempirical models is to establish a mathematical relationship (i.e., a re- gression) between the times of response and the explanatory variables, with no further consideration of mechanistic processes subjacent to the relation. Finally, the physically based methods rely on hydrological processes, as is the case with the velocity method (NRCS, 1986; see below).

Common equations are obtained in specific settings, which can be appropriate for a given geographical zone. For example, the Kirpich (1940) equation was developed in natural watersheds or those with crops, with a $3-10 \%$ slope with a channelized flow (Tucci, 2000). The Izzard (1946) method, derived from laboratory tests, is applicable to roads and pasture areas (Chow et al., 1988). Pasini (1914) and Giandotti (1940) formulae were obtained in rural basins in Italy, while the Temez (1978) formula is from Spain; all of these cases originated in a Mediterranean climate. CDH (1960) is for small mountain basins in the USA. Bransby-Williams (1922) developed his method for tropical India. The watershed lag method (USDANRCS, 2010) is for small rural watersheds where superficial flow dominates. Finally, ADOT (1993) was designed for semiarid Arizona (agricultural watersheds). In spite of the previous background information, in many cases no critical consideration of where these equations were obtained is carried out prior to their application. These equations' basic assumptions and the scope of their applicability is often not previously evaluated, they are simply applied to calculate a single LT or Tc, which are assumed to be true values with no further validation. Even worse, the official regulations of several countries are based on imported methods, as is the case in Latin America (de Almeida et al., 2017; DGA, 1995; Vélez and Botero, 2011).

The great diversity of formulae developed in many places around the world usually produce different results for the same location (de Almeida et al., 2014; Sharifi and Hosseini, 2011). This has led to a certain level of chaos that some authors have 
attempted to relieve by introducing some order in this regard. For example, Vélez and Botero (2011) recommended calculating the median of the estimations determined with different methods to obtain the correct Tc. Sharifi and Hosseini (2011) proposed a correction of the diverse methods in order to approach the reference Tc calculated by the velocity method (NRCS, 1986). De Almeida et al. (2014) classified 30 methods by means of a hierarchical cluster analysis. Moreover, de Almeida et al. (2017) determined that Ventura's method was the most appropriate for the Brazilian tropical region where they carried out their research.

On the other hand, Bentancor et al. (2014) compared the results of rainfall-discharge Tc determinations with the estimations obtained from three methods, and concluded that none produced the true values. The real merit of this work is that it revitalized the notion that LTs or Tcs are not unique for a given watershed, but depend on precipitation characteristics that are variable from storm to storm, as anticipated by Izzard's (1946) and Morgali and Linsley's (1965) equations. Thus, in this paper, we propose to advance the concept that LTs/Tcs are not fixed for a given watershed (i.e., parameters), but instead allow for variations within the same watershed as a function of rainfall properties (i.e., LT/Tc as variables).

Furthermore, in spite of the fact that some methods can produce accurate results when used in similar physiographical regions to where they were developed, they rarely have a hydrological basis, in contrast with the velocity approach (NRCS, 1986). This method has been considered by several studies as hydraulically sound and used as a reference to compare other estimations (McCuen et al., 1984; Sharifi and Hosseini, 2011; USDA-NRCS, 2010). In this paper, we tested the performance of the velocity approach utilizing more direct data obtained from a hyetograph-hydrograph analysis. We further compared our results with 24 equations, and developed the notion that $\mathrm{LT} / \mathrm{Tc}$ equations must include precipitation as a predictor.

\section{MATERIALS AND METHODS Study site}

This study was mainly conducted at the Estación Experimental Agropecuaria Austral (EEAA), located in the Los Ríos Region in southern Chile (39 $46^{\prime} 55^{\prime}$ S, $73^{\circ} 13^{\prime} 24^{\prime}$ ' W), 4 km north of the city of Valdivia, and $15 \mathrm{~km}$ from the Pacific Ocean (Fig. 1). The climate is humid temperate (Amigo and Ramírez, 1998), with an average annual temperature of $12^{\circ} \mathrm{C}$. Annual rainfall is $2,500 \mathrm{~mm}$; most of the rain is concentrated in the winter season (June-August). Snowfall is rare. Extreme temperatures during the period $2012-2015$ were $-1.4^{\circ} \mathrm{C}$ and $35.4^{\circ} \mathrm{C}$.

We studied the Santa Rosa watershed, whose creek is 5-6 m wide at its outlet, with a discharge of $58-1,151 \mathrm{~L} \mathrm{~s}^{-1}$ (in the summer and winter, respectively). The creek forms part of a watershed whose approximate area is $7.6 \mathrm{~km}^{2}$ (Fig. 1c), flowing through the middle of a $250 \mathrm{~m}$-wide native forest floodplain. A layer of loose sediment is found on the streambed, $34-109 \mathrm{~cm}$ thick.

In the flat zones, the geomorphology is mainly composed of alluvial terraces, with the uplands $\left(0.5-3^{\circ}\right.$ slope $)$ covered by pastures of Lolium perenne L. (perennial ryegrass). A slope covered by Nothofagus obliqua deciduous forest $(25 \mathrm{~m}$ wide, $35^{\circ}$ grade) then connects with the floodplain ( $4^{\circ}$ slope), which is covered by evergreen native forest. The pastures are located about $17 \mathrm{~m}$ a.s.l., while the Santa Rosa Creek is located $4 \mathrm{~m}$ a.s.l. The stream rises up to $160 \mathrm{~m}$ a.s.l. between 1.8 and $4.0 \mathrm{~km}$ upstream from the main study site (referred to as control point, P0, Fig. 1c), where second-growth, evergreen native forests and exotic tree plantations are found in the mountain headwaters.
The riparian vegetation (swamp forest) found in the floodplain is characterized principally by the trees Blepharocalyx cruckshanksii, Myrceugenia exsucca, and Drimys winteri var. chilensis, with few individuals of Nothofagus obliqua. However, there are vast zones in the floodplain covered by the herb Cyperus eragrostis (sedges), which grow either below gaps in the forest's canopy or in areas with low-stature trees. In terms of land cover, pastures account for $22 \%$ of the watershed, swamp forests $16 \%$, exotic tree plantations $0.74 \%$, secondgrowth evergreen forests $38 \%$, and second-growth deciduous forests on the foothills and the slope adjacent to the swamp forests the remaining $23.26 \%$ of the area.

All of the soils are derived from volcanic ash, but they belong to different orders. In the alluvial terraces adjacent to the control point, the soil corresponds to an Andisol, Valdivia series (Duric Hapludand or a Petroduric-Silandic Andosol; CIREN, (2003); WRB, 2006). On the upslope mountains, on the other hand, the soils belong to the order Acrisol (WRB, 2006) (also referred to as Ultisols; Soil Survey Staff, 1999). The corresponding series is Los Ulmos (CIREN, 2001). In general terms, volcanic ash soils are characterized by their very low bulk densities $\left(<0.9 \mathrm{Mg} \mathrm{m}^{-3}\right)$, high total porosity and water storage capacity, as well as very high values of saturated and unsaturated hydraulic conductivity. A detailed description of soils in the study area can be found in Dörner et al. (2013, 2015).

\section{Hydraulic measurements}

A HOBO U20-001-01 pressure logger (Onset Computer Corporation, Bourne, USA) was placed in the middle of the Santa Rosa stream from May 2014 to November 2015 (the P0 point, Fig. 1c). This equipment was hung from a steel chain connected to the top cap of a PVC tube. The barometric pressure compensation logger was also placed in the stream, but within a PVC tube that was closed at the bottom to prevent water from entering. The top end of this PVC tube was left open, but was isolated from rain with a non-hermetic plastic "hat". The same barometer was used for the compensation of all the loggers installed (see below). Measurements were taken every $15 \mathrm{~min}$, and the sensor error was $0.05 \%$ full scale (FS), where FS is $9.0 \mathrm{~m}$ (see also Cuevas et al., 2018).

To estimate variations in the times of response of four subcatchments nested within the Santa Rosa watershed, a more detailed survey was undertaken between December 2016 and March 2017. Four additional loggers were placed 622 (P1), 1759 (P2), 2608 (P3) and $2639 \mathrm{~m}$ (P4) upstream of P0. Two of these loggers were located in the swamp forest, at about the same altitude, while the two farthest points were $40 \mathrm{~m}$ a.s.l. in the mountainous forest, where two tributaries converge to form part of the main reach (Fig. 1c). Thus, P3 and P4 belonged to the sequence P0- P1- P2- P3 (or P4), but the latter two did not form part of the same drainage area. The stream channel is present throughout the watershed, but is surrounded by floodplains from P2 downstream, and through most of the extension of the northern reach on the western side of the watershed (Fig. 1c).

Due to the availability of equipment, a Levelogger Junior sensor (model 3001, Solinst, Ontario, Canada) had to be used at $\mathrm{P} 1$, while at the other stations we employed HOBO dataloggers. The Solinst sensor has an error of $\pm 0.1 \%$ FS, where FS is $10 \mathrm{~m}$.

Stream velocities were measured with a Seba F1 current meter (Eijkelkamp, The Netherlands) at the studied P0 stream reach, $100 \mathrm{~m}$ upstream and $100 \mathrm{~m}$ downstream. They were measured at 20 and $80 \%$ of the stream depth, in several sections of each of the three studied transects, and 11 times from 


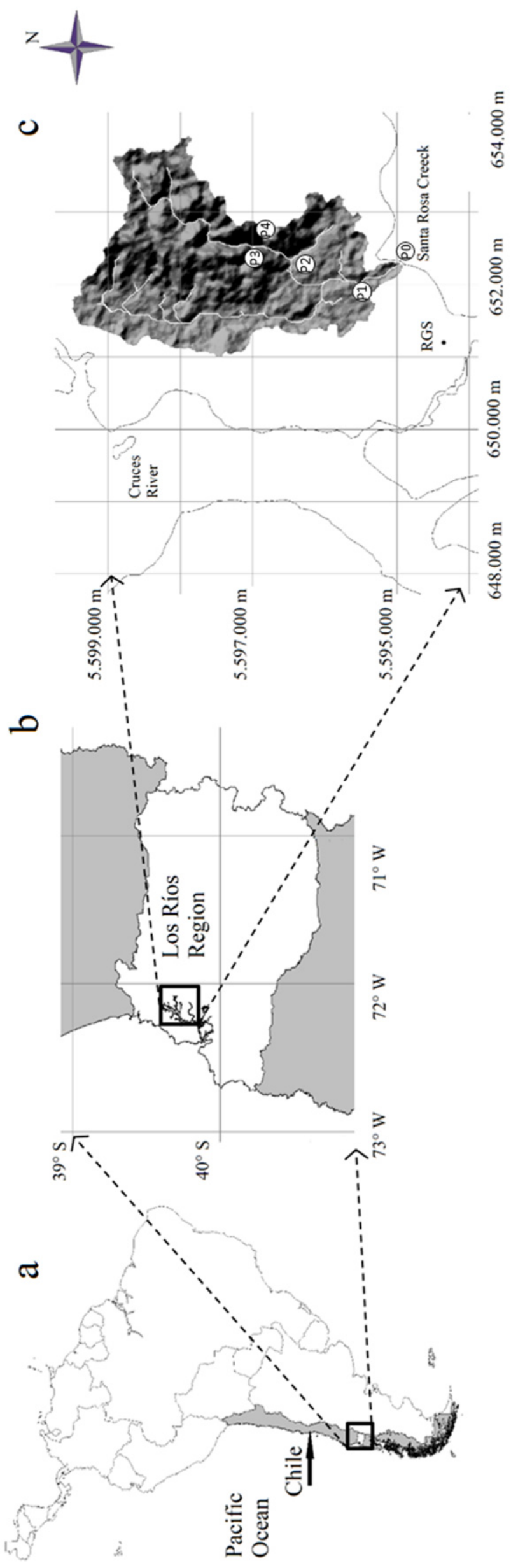

Fig. 1. (a) Location of the study site in southern Chile, in (b) the Los Ríos Region. (c) Delimitation of the Santa Rosa watershed. The labels P0 to P4 indicate gauge points. Streams flow through floodplains indicated by a lighter color, downstream of $\mathrm{P} 2$, and through most of the extension of the northern reach on the western side of the watershed. RGS: EEAA rain gauge station. The other station (Miraflores) was located $6 \mathrm{~km}$ to the south.

December 2012 to August 2015. The measurements carried out at the three monitoring points were averaged to provide a single value. Additional spot velocity gathering was carried out in March 2017 at P1, P2, P3, and P4. Measurements were not taken before and after a given peak flow (see Discussion: Velocity method estimation).

Two meteorological stations were utilized in this study: one was located at the same experimental station (EEAA, Fig. 1c), $1.2 \mathrm{~km}$ from the watershed outlet (Campbell Scientific CR 1000 instruments, Logan, UT, USA, available from http://agromet.inia.cl); and the other, referred to as Miraflores (https://www.centroccbb.cl/clima/), was $6 \mathrm{~km}$ from the study site in the city of Valdivia (Davis Vantage Pro 2 weather station, Hayward, CA, USA). However, only the latter had a long data record encompassing almost all of the study period, while the EEAA station only began operating in May 2015. In the main study, we chose to use the Miraflores records to have a larger sample size, but we compared these records with those obtained from EEAA for the common period (May-November 2015). Conversely, for the shorter study of stream stage variation along the stream, rainfall data was obtained from the EEAA station. The Davis station accumulated the rainfall data in 30 min periods ( $0.2 \mathrm{~mm}$ resolution), while the Campbell station reported data hourly $(0.1 \mathrm{~mm}$ resolution $)$.

\section{Determination of lagtimes}

Lagtimes were defined as the time lapse between the middle point of the rainfall event and the discharge peak (USDANRCS, 2010; Vélez and Botero, 2011). The middle point was determined as half the time between the start and the end of the rainfall. For these analyses, only well-defined precipitation events and discharge peaks were considered.

We revised the literature to locate a large number of methods (24) proposed to calculate Tc or LT, especially the works of de Almeida et al. (2014), Sharifi and Hosseini (2011), and USDA-NRCS (2010). The formulations of some selected equations appear in Appendix 1. Most equations require knowledge regarding watershed physiographic characteristics, such as area, length of the main channel, channel slope, watershed slope, altitude, etc. (Table 1). This knowledge was obtained from a combination of Google Earth Pro imagery (version 7.1.7.2600; Google Inc., Mountain View, CA, USA) and Geographic Information Systems. This was necessary because no official topographic maps with adequate spatial resolution for this study were available for the area. Consequently, we constructed a digital elevation model (DEM) with a $12.5 \mathrm{~m}$ x $12.5 \mathrm{~m}$ resolution obtained from the Alaska Satellite Facility web page (https://vertex.daac.asf.alaska.edu/), which, in turn, acquires images from NASA. With this DEM, we generated a three dimensional model (Fig. 1c) with ArcMap 10.3.1 software (ESRI, Redland, CA, USA); this was used to calculate required input variables.

We then calculated the Tc or LT utilizing each one of the methods. As our analysis was focused mainly on LT, while 
Table 1. Variables and parameters used for the calculation of lagtimes and times of concentration in the Santa Rosa watershed and subcatchments.

\begin{tabular}{|c|c|c|c|}
\hline Name & Abbreviation & Value & Unit \\
\hline 2-year, 24-h rainfall & $\mathrm{P}_{2}$ & 93 & $\mathrm{~mm}$ \\
\hline Basin development factor & BDF & 0 & - \\
\hline Cross-sectional flow area & $\mathrm{a}$ & 0.33 (in P3) to 4.0 (in P0) & $\mathrm{m}^{2}$ \\
\hline Diameter of the circle equivalent to watershed area & Dc & 3.11 & $\mathrm{~km}$ \\
\hline Impervious area in the watershed & IMPERV & 2 & $\%$ \\
\hline Length of the main channel & $\mathrm{L}$ & 5.48 & $\mathrm{~km}$ \\
\hline Length of the shallow concentrated flow & $\mathrm{L}_{\mathrm{s}}$ & 145 & $\mathrm{~m}$ \\
\hline Length of the open channel flow (reach 1, upstream) & $\mathrm{L}_{1}$ & 560 & $\mathrm{~m}$ \\
\hline Length of the open channel flow (reach 2, downstream) & $\mathrm{L}_{2}$ & 4,920 & $\mathrm{~m}$ \\
\hline Main channel slope & $\mathrm{S}$ & 0.0111 & $\mathrm{~m} / \mathrm{m}$ \\
\hline Manning's channel roughness coefficient (Chow, 1959) & $n$ & 0.11 (dense brush, flood stage reaching branches) & $\mathrm{m}^{-1 / 3} \mathrm{~s}$ \\
\hline Manning's roughness coefficient for sheet flow & $n$ & 0.80 (dense underbrush) & $\mathrm{m}^{-1 / 3} \mathrm{~s}$ \\
\hline Maximum watershed altitude for the longest channel & Hmax & 70 & $\mathrm{~m}$ a.s.1. \\
\hline Mean watershed elevation & $\mathrm{Hm}$ & 61 & $\mathrm{~m}$ a.s.1. \\
\hline Minimum watershed altitude & Hmin & 9 & m a.s.1. \\
\hline Rainfall intensity & $\mathrm{i}$ & 3.7 (high intensity), 0.03 (low intensity) & $\mathrm{mm} / \mathrm{h}$ \\
\hline Retardance coefficient (Izzard, 1946) & $\mathrm{cr}$ & 0.06 & - \\
\hline Retardance factor, runoff curve number (USDA-NRCS, 2010) & $\mathrm{cn}, \mathrm{CN}$ & 72 (mean for woods, pasture, meadow grass in C soil type) & - \\
\hline Slope terrain in headwaters & $\mathrm{S}_{\mathrm{h}}$ & 0.174 & $\mathrm{~m} / \mathrm{m}$ \\
\hline Watershed area & A & 7.6 & $\mathrm{~km}^{2}$ \\
\hline Watershed mean slope & $\mathrm{Y}$ & 12.43 & $\%$ \\
\hline Wetted perimeter & $\mathrm{P}_{\mathrm{w}}$ & 1.7 (in P3) to 6.6 (in P0) & $\mathrm{m}$ \\
\hline
\end{tabular}

most equations deal principally with Tc, we applied the following formula (USDA-NRCS, 2010; Vélez and Botero, 2011):

$L T=0.6^{*} T c$

The velocity method (NRCS, 1986) was analyzed in detail and is explained in Appendix 2 (Equations (A12-A14)). Briefly, it involves the estimation of stream velocities based on hydraulic considerations. The distances where those flows occurred were divided by the velocities, so that the travel times could be determined. The sum of the travel times was then considered as the time of concentration. Although dividing the watershed into three segments along its course is recommended, we chose to use only two segments because there are only two main physiographic units (the upslope mountains above P2, and the lowland, flat area below P2).

\section{Data analyses}

Measured LTs were related to common distribution frequencies (Gumbel, Non-normal, Gamma, Weibull, Lognormal, Normal, Rayleigh, and Exponential). The departures between the theoretical distribution and the observed values were evaluated with the Kolmogorov-Smirnov test (Sokal and Rohlf, 1995) (Module Industrial Statistics \& Six Sigma/ Process Analysis of Statistica 7.0 software, StatSoft, Inc., Tulsa, OK, USA).

We then compared the observed LTs with the predicted values from 24 methods, and selected the equations with the best agreements. These were improved through the inclusion of rain variables that produced good relationships with LTs, as determined by linear regressions analysing the rain amount per event, rain intensity, event duration, and accumulated rainfall for the seven days prior to the discharge peak. Since most Tc equations are non-linear (Appendix 1) we estimated the new parameters, which are exponents of the input variables, with the Nonlinear Estimation module of Statistica 7.0 software. This procedure operates through the Levenberg-Marquardt algorithm, which carries out a maximum of 50 iterations to minimize the least-squares among observed and predicted LTs from the equations.

\section{RESULTS}

\section{Temporal variability of lagtimes at $\mathrm{P0}$}

Throughout the period May 2014-November 2015, we detected 100 precipitation events at the Miraflores station that were able to induce rises in streamflow. The highest discharge peak for the year 2014 was due to a rain event of $100 \mathrm{~mm}$ in 24 $\mathrm{h}$, which caused a rise in the hydrograph from $<400$ to 1,151 $\mathrm{L} \mathrm{s}^{-1}$. Even under this extreme scenario, the LT was $22 \mathrm{~h}$. Overall, LTs ranged from 0.6 to $58.5 \mathrm{~h}$, with a mean of $20.1 \mathrm{~h}$. When analyzing data from the EEAA meteorological station, the mean LT was $20.4 \mathrm{~h}$ (ranging from 0.6 to $50.5 \mathrm{~h}, N=46$ events). The frequency distribution derived from the Miraflores data was slightly skewed to the right (Fig. 2). All assayed fittings produced non-significant deviations with respect to common theoretical distributions (with the exception of the exponential distribution), while Gumbel produced the lowest Kolmogorov-Smirnov departure $\left(d_{\max }=0.051, P>0.05\right.$, Fig. 2$)$. When comparing LTs corresponding to autumn, winter, spring, and summer, the median values were $20.2,17.7,20.5$, and 16.2 h, respectively (Fig. 3).

\section{Spatial variability of lagtimes along the stream}

During storm events, the stream stage variation along the stream was evaluated for 11-15 events in the summer of 2017. In Fig. 4, the curves for a representative period are shown. It can be clearly seen that the highest subcatchments anticipated their response to rainfall compared with the lowest subcatchments. In other words, as the size of the nested catchments decreased, the LT also decreased (Table 2). P0 showed a LT very similar to the previous summer (mean 16.0 vs. 17.0 h), even though the sample sizes were not the same $(N=4$ in 2015; $N=14$ in 2017). The difference in LTs among the highest stations (P3, P4) and the lowest was about $10 \mathrm{~h}$. 


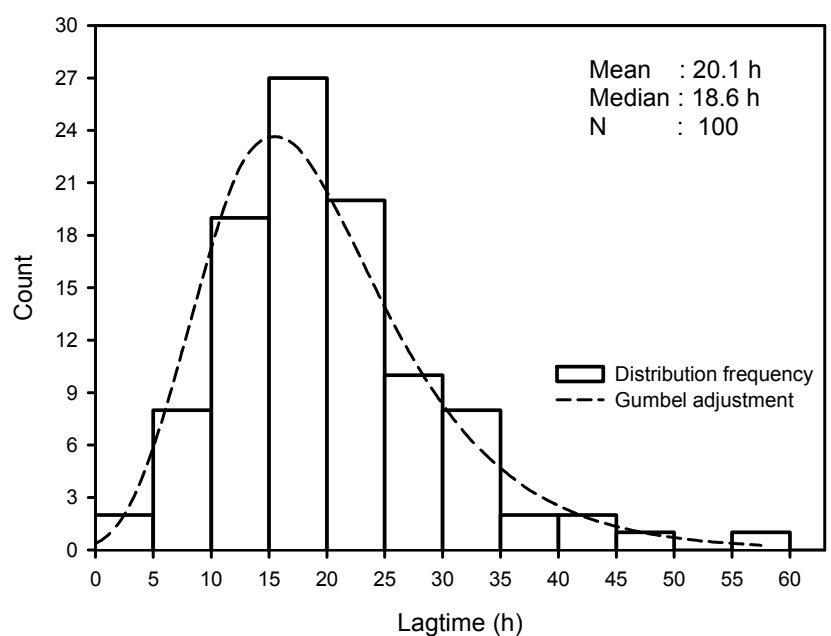

Fig. 2. Frequency distribution of the lagtimes measured from the hyetograph-hydrograph analyses at the P0 point in the Santa Rosa watershed. The Gumbel distribution was adjusted to the observed data.

Table 2. Lagtimes in subcatchments nested within the Santa Rosa watershed for the period December 14, 2016 - March 9, 2017.

Subcatchment points of measurement

\begin{tabular}{lccccc} 
Lagtime (h) & P0 & P1 & P2 & P3 & P4 \\
\hline & & & & & \\
Mean & 17.0 & 14.2 & 8.1 & 6.1 & 7.2 \\
Max & 27.8 & 22.2 & 17.8 & 16.5 & 15.3 \\
Min & 10.2 & 8.5 & 4.5 & 3.0 & 3.0 \\
Sample size & 14 & 14 & 11 & 15 & 14 \\
\hline
\end{tabular}

\section{Calculated lagtimes}

Most equations that mainly account for the physiographic characteristics of a watershed produced estimations that severely underestimated the observed LTs (Table 3). For example, the Kerby (1959) method predicted a LT $=0.21 \mathrm{~h}$. Even the formula that is currently used in Chile (DGA, 1995; USA California Division of Highways, 1960; Equation (A2) (Appendix 1)) showed a LT $<1 \mathrm{~h}$. The Soil Conservation Service, Texas (USDA-NRCS, 2010), fell in the mid-range among the estimations (LT $=2.8 \mathrm{~h}$ ) (Equation (A4), Appendix 1). One of the Granato (2012) formulae (RE07, Equation (A7) in Appendix 1) ranked fourth in decreasing order with a $\mathrm{LT}=$ $10.4 \mathrm{~h}$. There were three additional equations that produced

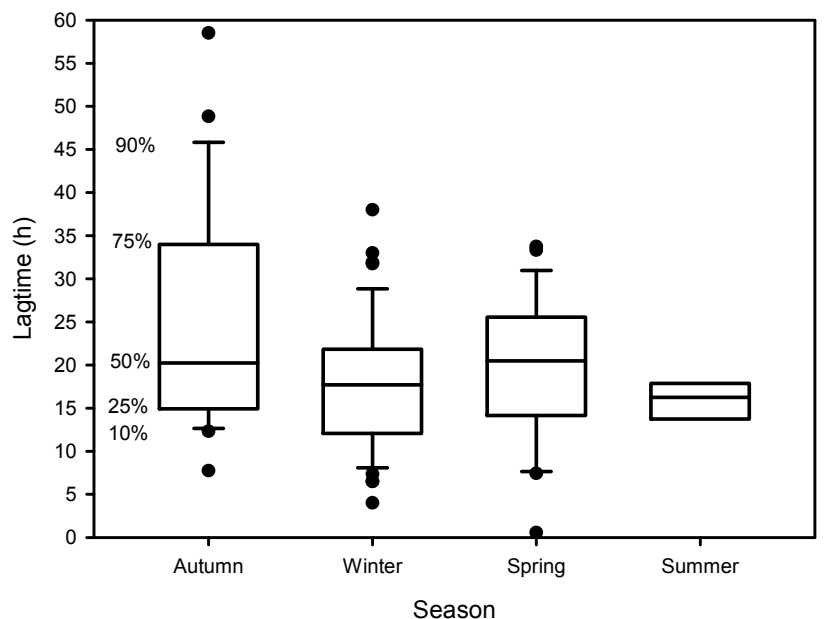

Fig. 3. Box plots for lagtimes at the P0 point of the Santa Rosa stream, as a function of season. The percentages adjacent to the boxes indicate the percentiles, and the dots are the outliers.

LTs approaching the observed values and allowed for varying estimations according to rainfall intensities. This was the case for the Izzard (1946) Equation (A11) (Appendix 1), which predicted LTs of $10.4 \mathrm{~h}$ for the highest rain intensity measured for the period $\left(3.7 \mathrm{~mm} \mathrm{~h}^{-1}\right)$, and $258 \mathrm{~h}$ with $0.03 \mathrm{~mm} \mathrm{~h}^{-1}$, the lowest rain intensity. On the other hand, Papadakis and Kazan (1986) Equation (A9), (Appendix 1) and Morgali and Linsley (1965) (Equation (A10) in Appendix 1) only produced good agreements at low rain intensities. The median for the calculated LTs was $2.4 \mathrm{~h}$.

\section{The velocity method}

This method approached the observed results and deserves a separate analysis (Equations (A12-A14), Appendix 2). For point $\mathrm{P} 0$, the estimated travel time ( $\mathrm{Tt}$ ) for sheet flow was $0.15 \mathrm{~h}$, while the velocity of the shallow concentrated flow would be 0.305 $\mathrm{m} \mathrm{s}^{-1}$ for a slope of $0.174 \mathrm{~m} / \mathrm{m}$. Since the segment length for that flow was $145 \mathrm{~m}$, then the $\mathrm{Tt}$ (concentrated flow) was $0.13 \mathrm{~h}$.

For the mountainous area, the open channel flow was applied to the first reach length of $560 \mathrm{~m}$ with a calculated velocity of $0.91 \mathrm{~m} \mathrm{~s}^{-1}$, that is, $0.17 \mathrm{~h}$ of travel time. In the lower reach, which is $4,920 \mathrm{~m}$ long, a velocity of $0.23 \mathrm{~m} \mathrm{~s}^{-1}$ was estimated, making the equivalent $\mathrm{Tt} 6.0 \mathrm{~h}$. Thus, the total travel time was $6.4 \mathrm{~h}(\mathrm{LT}=3.8 \mathrm{~h})$, based on velocity estimations.

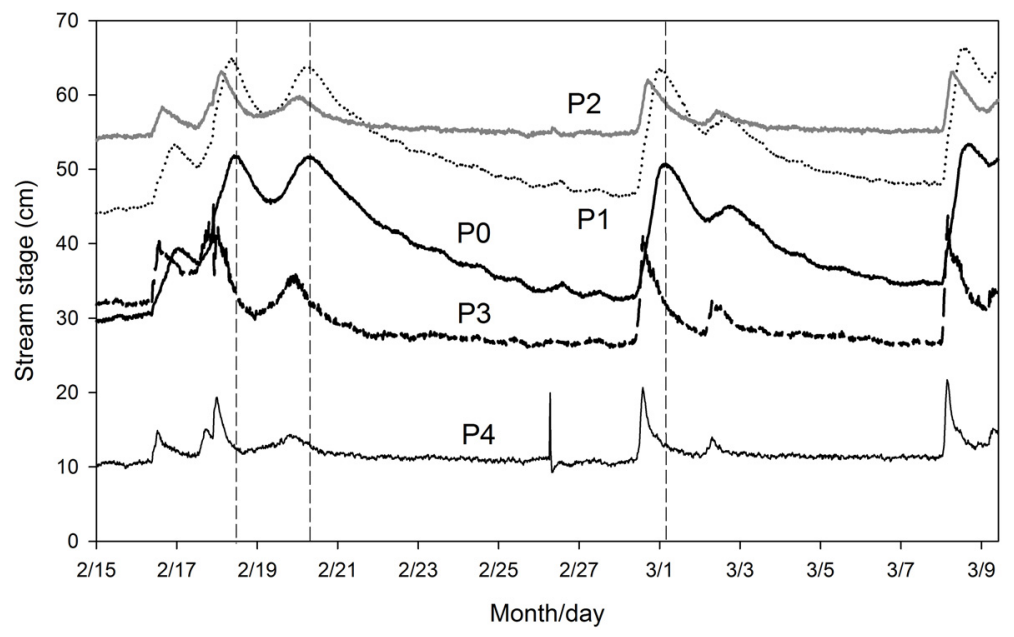

Fig. 4. Variations in stream stage in different subcatchments nested within the Santa Rosa watershed. P0 was the lowest gauge point, and P1, P2, P3 and P4 were located at increasing distances upstream from P0. P3 and P4 were located in different tributaries of the main channel. To facilitate comparisons of timing of different stations, three vertical dashed lines out of the several stage peaks shown have been drawn to coincide with the P0 peaks. A representative period in the year 2017 was selected from a longer three month-evaluation. 
Table 3. Estimations of lagtimes (LT) for the Santa Rosa watershed in southern Chile at point P0. Estimations appear in increasing order of LTs.

\begin{tabular}{lc}
\hline Method & LT (h) \\
\hline & \\
USDA (Argente-Sanz, 2014) & 0.065 \\
Kerby (1959) & 0.21 \\
Simas (1996) I & 0.3 \\
California Division of Highways (1960) & 0.8 \\
Kirpich (1940) & 0.9 \\
Soil conservation service: Ohio (USDA-NRCS, 2010) & 1.0 \\
Watershed lag method (USDA-NRCS, 2010) & 1.2 \\
Dirección General de Carreteras (Témez, 1978) & 1.5 \\
Simas (1996) II & 1.6 \\
Bransby-Williams (1922) & 1.6 \\
Giandotti (1940) & 1.8 \\
Ventura (Mata-Lima et al., 2007) & 2.0 \\
Soil conservation service: Texas (USDA-NRCS, 2010) & 2.8 \\
Folmar and Miller (2008) & 3.2 \\
Granato (2012) RE03 & 3.5 \\
Pasini (1914) & 3.9 \\
Sheridan (1994) & 6.3 \\
Granato (2012) RE13 & 7.4 \\
Granato (2012) RE06 & 7.9 \\
Velocity method (NRCS, 1986) & $3.8-9.4$ \\
Granato (2012) RE07 & 10.4 \\
Papadakis and Kazan (1986) & $2.4-14.6$ \\
Morgali and Linsley (1965) & $3.6-24.7$ \\
Izzard (1946) & $10.4-258.3$ \\
\hline
\end{tabular}

Table 4. Stream velocity for different measurement dates in the Santa Rosa Creek (P0 point).

\begin{tabular}{lc}
\hline Date & $\begin{array}{c}\text { Water velocity }\left(\mathrm{cm} \mathrm{s}^{-1}\right) \\
(\text { mean } \pm \text { SE) }\end{array}$ \\
\hline December $4^{\text {th }}, 2012$ & $6.2 \pm 1.27$ \\
May $2^{\text {nd }}, 2013$ & $10.5 \pm 1.29$ \\
July $23^{\text {rd }}, 2013$ & $11.8 \pm 1.59$ \\
June $2^{\text {nd }}, 2014$ & $8.6 \pm 3.10$ \\
June $13^{\text {th }}, 2014$ & $10.3 \pm 0.86$ \\
December $23^{\text {rd }}, 2014$ & $8.9 \pm 1.26$ \\
January $9^{\text {th }}, 2015$ & $7.4 \pm 1.13$ \\
February $9^{\text {th }}, 2015$ & $5.9 \pm 1.09$ \\
June $1^{\text {st }}, 2015$ & $12.9 \pm 1.80$ \\
June 26 & th, 2015 \\
August $6^{\text {th }}, 2015$ & $9.6 \pm 1.45$ \\
Mean & $8.6 \pm 0.69$ \\
\hline
\end{tabular}

However, as we directly measured the stream velocity at P3 $\left(0.29 \mathrm{~m} \mathrm{~s}^{-1}\right)$ and P0 (mean $0.092 \mathrm{~m} \mathrm{~s}^{-1}$, Table 4), we were able to correct the velocity estimations for the open channel flow, resulting in the following travel times for the first and second reaches: 0.54 and $14.9 \mathrm{~h}$. Thus, the recalculated total $T t$ was $15.7 \mathrm{~h}(\mathrm{LT}=9.4 \mathrm{~h})$.

\section{Improvement of methods of LT estimation}

We took note of the improved predictive power of the three methods that included rainfall intensity as a variable (Izzard, 1946; Morgali and Linsley, 1965; Papadakis and Kazan, 1986). We tested whether there was a significant relationship between observed LTs and the rainfall amount, rainfall intensity, and rainfall duration per event, in addition to the total accumulated rainfall for the seven days prior to the discharge peak. Some relationships were poor, evidenced by their extremely different observed LTs for the same rain amount and intensity (Figs. 5 a, $\mathrm{b}, \mathrm{d})$. Conversely, the relationship was much better for rainfall duration vs. LT ( $\left.r^{2}=0.691, r=0.831, P<0.0001\right)$ (Fig. 5c). Our conclusions were the same when carrying out these analyses with the EEAA rain data; although the $r^{2}$ values were lower due to the lower sample size. The distributions of both rain intensity and duration were skewed to the right, with mean values of $0.94 \mathrm{~mm} \mathrm{~h}^{-1}$ for the first (Fig. 6a) and $27.7 \mathrm{~h}$ for the last variable (Fig. 6b).

The lack of fit of rainfall intensity with LT was confirmed by directly introducing the values of the former variable within the selected equations, which produced a poor relationship between predicted and observed LT values (data not shown). We then included rainfall duration as a predictor in the equations. For example, Izzard's equation could be modified to:

$$
L T_{\bmod }=\frac{0.6 * 526.42 *\left(0.0000276 * D^{a}+b\right) * 17.62}{0.2233 * D^{c}}
$$

where $L T_{\text {mod }}$ is the modified Izzard equation, 0.6 is the factor for converting Tc into LT, 17.62 is $\mathrm{L}^{1 / 3}$ (L, main channel length in $\mathrm{m}), 0.2233$ is $\mathrm{S}^{1 / 3}(\mathrm{~S}$, main channel slope, $\mathrm{m} / \mathrm{m}), D$ is the rainfall duration in hours, and $a, b$, and $c$ are parameters to be adjusted. The other constants come from Izzard's Equation (A11) (Appendix 1).

Following this procedure, the formulae presented by Morgali and Linsley (1965) and Papadakis and Kazan (1986) provided an $r^{2}=0$ when relating to observed LTs, because the non-linear form of these Equations (A10) and (A9) (Appendix 1) could not account for the linear relation that is subjacent to LT versus D. On the other hand, the non-linear regression produced the following estimations for Izzard: $a=0.992448, b=0.000357$, and $c=0.094489$. The coefficient of correlation was $r=0.828$ and the coefficient of determination was $r^{2}=0.685(P<0.001$ for model). If $b$ would have been fixed as $0.06-0.09$ (the values of the retardance factor for dense pastures and forest plantations, respectively; Bentancor et al., 2014), $r^{2}$ would also have been zero.

Parameters $a, b$, and $c$ were then introduced into Equation (2). The predictions of this equation were tested against the observed LTs, resulting in a linear relationship where points were distributed at both sides of the 1:1 relationship (Fig. 7), being a reasonable adjustment with observed data. The same conclusion was obtained in the analysis with EEAA rainfall data.

\section{DISCUSSION \\ Comparison among methods of LT estimation}

Our measured lagtimes were rather long (mean $20 \mathrm{~h}$ ), and had a good fit with the Gumbel distribution, a probability density function that is commonly used to describe extreme values, usually high, that rarely occur with respect to most values in the distribution (Gumbel, 1960). Long LTs have also been observed by de Almeida et al. (2017) and have resulted in smooth rises and recessions of hydrographs. The resulting rounded forms contrast with the sharp forms observed in torrential watersheds (Singh and Singh, 2017). It is likely that the large floodplain extension, in both length and width, as well as the type of vegetation, contributed to this pattern. In fact, Granato (2012) points out that lakes, ponds, and wetlands are zones of surface storage, which only some studies explicitly include.

In this study, most equations that only included physiographic watershed characteristics produced estimations that severely underestimated the observed LTs, while those including rainfall properties or stream velocities produced much 

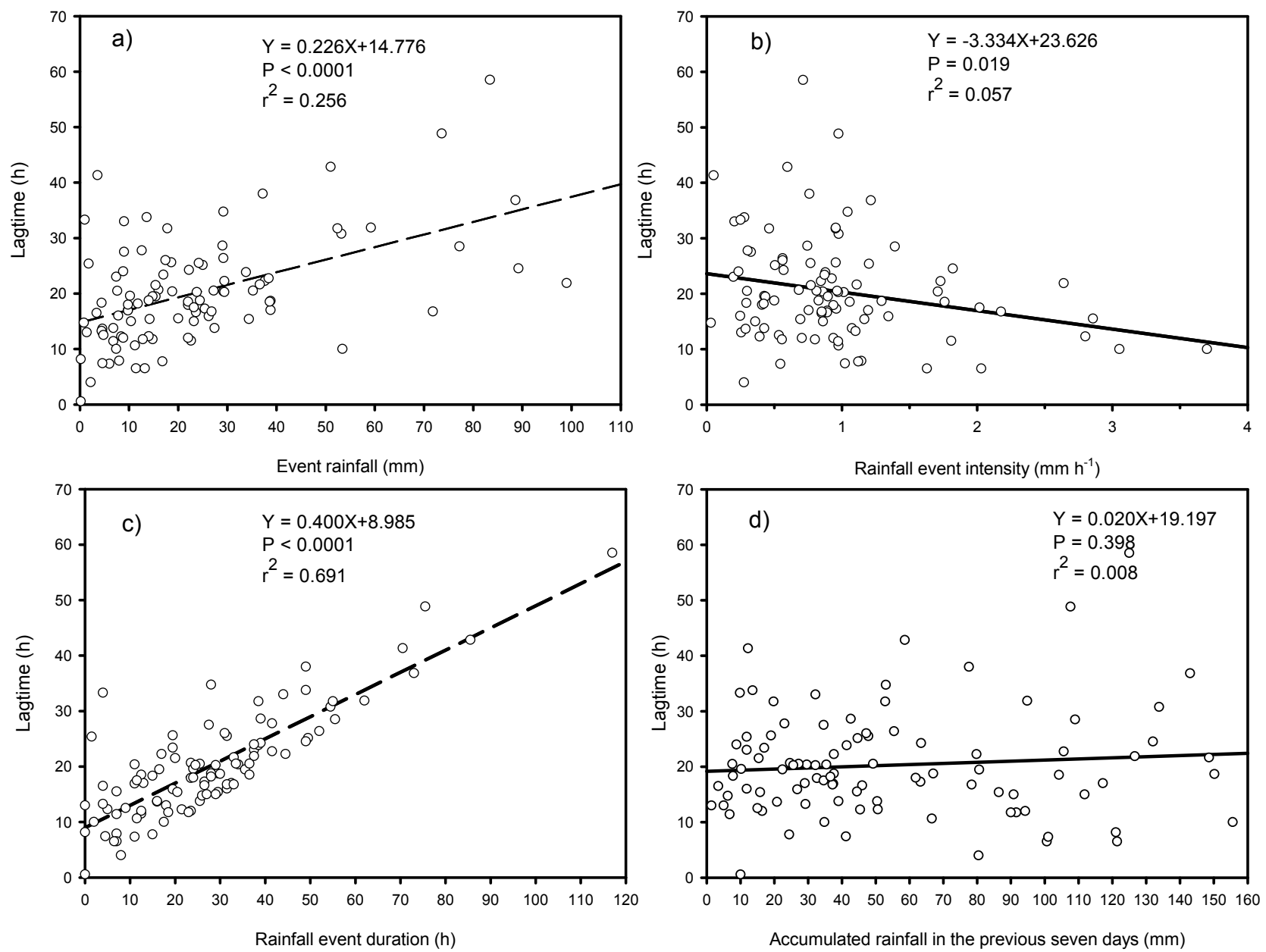

Fig. 5. Linear regressions of different precipitation expressions and lagtimes between the rainfall event and the discharge peak at point $\mathrm{P} 0$. Linear equations, model probability (P) and coefficient of determination $\left(r^{2}\right)$ are shown in each panel.

better estimations. An exception to this statement was the Granato (2012) RE07 equation, which produced an estimation of $50 \%$ of the observed value, partially including physiography. The relative success of this formula may be related with the fact that the model was specially developed for predicting lagtimes, and accounted for urbanization and the prevalence of engineered drainage features as well (Granato, 2012).

In general, simple watershed attributes such as area, slope, main channel length, and difference in elevation between headwaters and outlets, cannot adequately describe the impediments that water must face throughout its travels along the watershed. In other words, equations that only include physiographic factors assume that only the distance effect could cause a delay in the water's travel time, thus presuming that the substrate is smooth. This assumption would only be valid for urban watersheds, for those with a rocky streambed, or with low vegetation cover. In forested swampy watersheds there is a retardance factor that is not adequately included in the diverse equations examined here. In the studied catchment, the streambed was made up of loose sediments that are home to an extensive hyporheic zone, where water flows are likely to be considerably slower than in open channels (Edwards, 1998). Many tree stems also cross the watercourse, and in the mountain headwaters the presence of dense Chilean bamboo thickets ("quilas") is a factor that can delay the water's movement. Moreover, there is a large cover of Cyperus sedges along the floodplain. Sedges inhabit places with a very high groundwater table, even above the ground level for most of the year. When the plains are completely flooded throughout the winter, the impediments for water movement are even greater, and possibly higher than in the forest where stems have a lower density than sedges.

At first sight, the use of some of the evaluated equations was not justified to predict the specific response of the swampy, forested watershed. However, since our aim was to find out which formula was the most appropriate for describing the studied watershed's behaviour, we evaluated all 24 equations most commonly found in the literature. Overall, the calculation of the median to determine the best LT estimation, as recommended by Vélez and Botero (2011), was not successful. The large bias in the number of methods that predicted low LTs produced inaccurate results.

\section{Spatial-temporal variations in lagtime}

Our results show that the peak discharge caused by rain appeared earlier in the stations located at the headwaters in forested mountainous areas. The maximum appeared progressively later downstream. Thus, lagtimes were shorter at the headwaters than in the lowlands, coherent with a flood wave that moves from areas high in the mountains (ridges and slopes covered by second-growth evergreen native forests and exotic tree plantations) to the lowland zones covered by swamp forest. There was a delay of 10 hours due to the great distance between highlands and lowlands, compounded by the great areal extension, high roughness, and low slope of floodplains. 

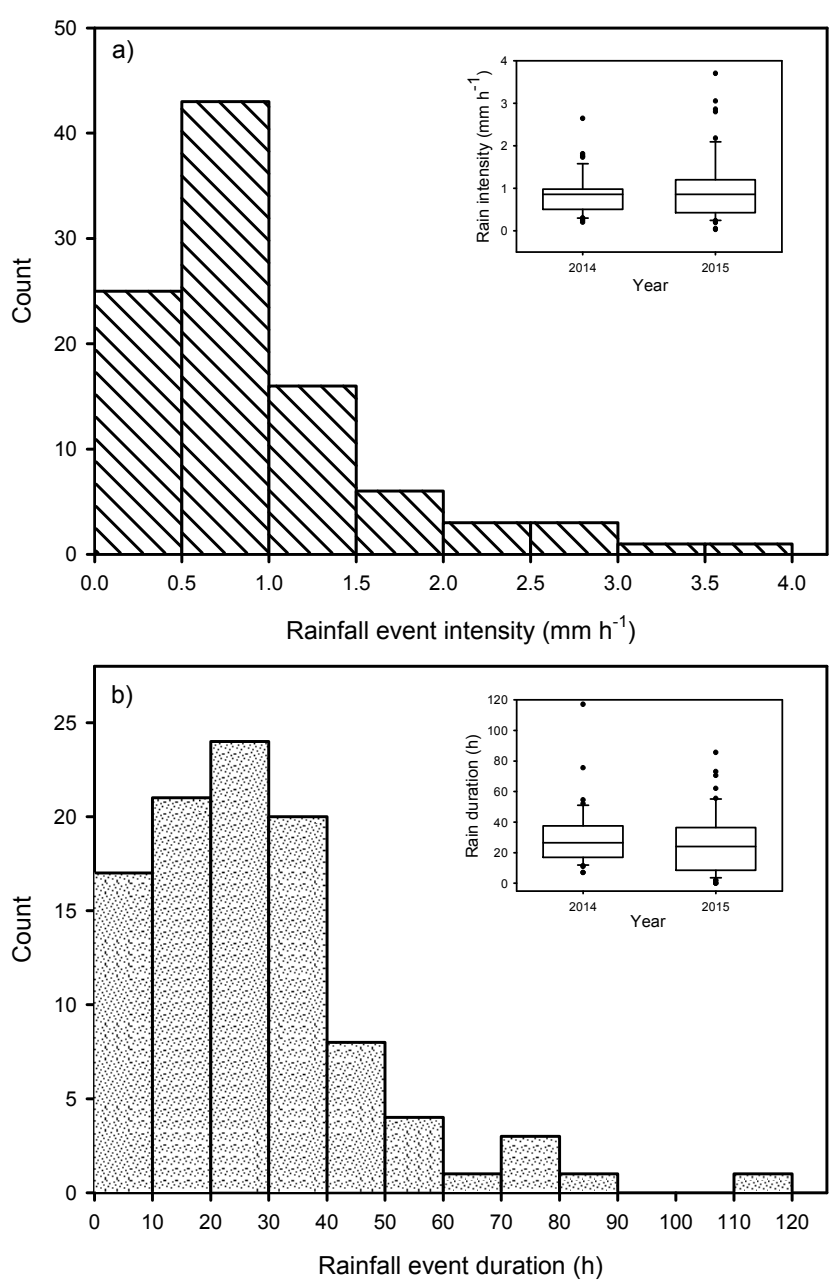

Fig. 6. Distribution frequency of rainfall event intensity (a) and duration (b). Inserted graphs show the values for the years 2014 and 2015, using the same convention as Fig. 3 for boxplots.

A source of uncertainty in this analysis is the assumption that the storms arrived simultaneously to all of the gauging points, since only one meteorological station was used for the hyetograph-hydrograph analysis (EEAA). However, as the watershed is only $4 \mathrm{~km}$ long, and we have proven that LTs derived from the farthest station (Miraflores) are very similar to those obtained from EEAA, it is very likely that this pattern also occurs within the watershed. Moreover, the differences in LTs among monitoring points were several hours, making it unlikely that a small difference in storm timing across these points would mask such a significant time difference.

\section{Velocity method estimation}

This method relies on the estimation of water velocity for sheet flow and shallow concentrated flow, values that are difficult to measure in the field. However, even allowing for some uncertainty in these estimations, these flows scarcely contributed in terms of total length $(160 \mathrm{~m})$ and travel time $(0.27 \mathrm{~h})$ in comparison with the longest stream segments in the watershed $(5,480 \mathrm{~m}, T t=6.2 \mathrm{~h})$. Bentancor et al. (2014) also considered sheet flow negligible based on the small percentage of watershed area where that flow occurs. Therefore, any discrepancy between observed Tcs or LTs and the estimated values must be searched for in the stream velocities of the longest segments. For these reaches, Tt increased up to $15.4 \mathrm{~h}(\mathrm{LT}=9.2 \mathrm{~h})$ when including measured stream velocities in the field. Thus,

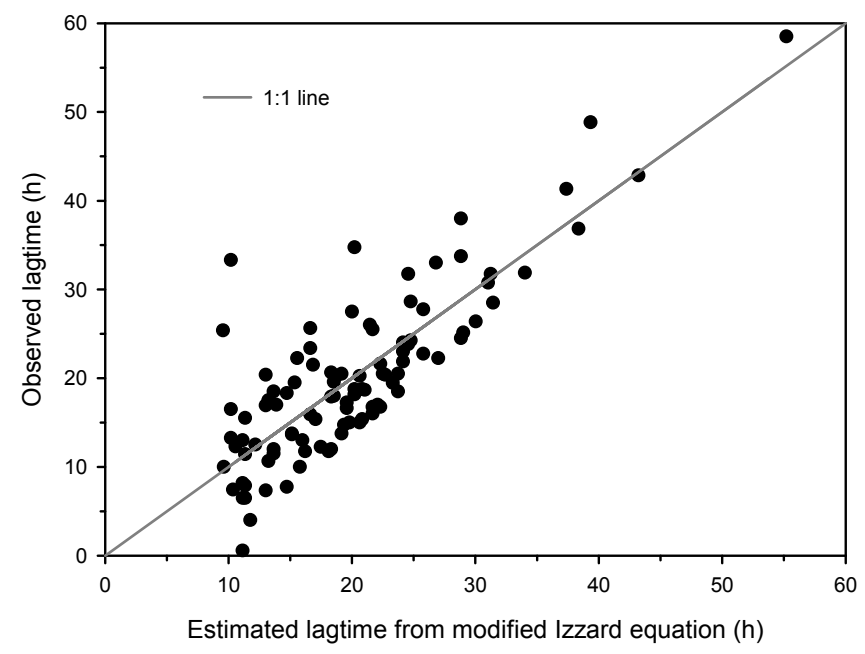

Fig. 7. Comparison of estimated lagtimes calculated with the modified Izzard (1946) equation and those observed in the Santa Rosa watershed (P0 point). The correlation between both variables was $r$ $=0.828\left(r^{2}=0.685\right)$.

methodologically, it is preferable to collect these data, rather than estimating them from hydraulic radiuses that are more difficult to measure in many locations along the main stream channel. In addition, the roughness coefficient included in Manning's Equation (A14) (Appendix 2) can be spatially variable, and can perhaps vary in the time domain as well. Even with the corrections of our spot velocity measurements, the calculated LTs still fell short of the observed values (mean $20 \mathrm{~h}$ ), but it must be considered that the $\mathrm{P} 3$ datum was only based on velocity surveys for the summer of 2017. Furthermore, travel times and, consequently, LTs can show large fluctuations if we take into account that stream velocity changes along the channel, in addition to changing daily, monthly and seasonally (Table 4) as a direct function of streamflow (data not shown; see also Wondzell et al., 2007). Even the precipitation factor can influence stream velocity via the discharge magnitude. Thus, the velocity method is promising since it showed one of the highest LT estimations in our data, and because it allows for LT variations throughout time. Further research should measure stream velocities on at least a daily scale to establish relationships with discharge and observed LT/Tc.

\section{Improvement of methods of LT estimation}

LT varied as a function of rainfall properties, as noted by Bentancor et al. (2014), with rainfall duration being the variable that best explained the LT variation. Contrasting with our results, when Bentancor et al. (2014) evaluated (in Uruguay) the three methods developed by Kirpich, Morgali and Linsley, and Izzard the observed Tcs were overestimated. Possible explanations may be related to the dominance of pastures in that country, with no trees in the riverbanks nor submerged in the water (L. Bentancor, personal communication).

The relationship between LT and rainfall duration is most likely due to the fact that each storm pulse generates a response hydrograph, which is added to the response of the other pulses (Chow et al., 1988). In other words, a longer storm causes a response with a longer duration. Rainfall duration also had the least departure from the Gumbel distribution as compared to standard distributions (data not shown), coinciding with the LT frequency distribution.

The predictive value of the Izzard equation, which included precipitation as a variable, could be further improved upon. The 
parameters that represent exponents of duration ( $a, c)$ could be statistically well adjusted. However, $b$ in the original Equation (A11), (Appendix 1) corresponded to the retardance factor (cr). Our result with the modified equation was $b=0.000357$, which is very low compared to the recommended $\mathrm{cr}$ for Izzard's equation ( $c r=0.06-0.09$, Bentancor et al., 2014). Fixing this factor to these values was not possible because the resulting equation had a very poor fit. Therefore, $b$ cannot be strictly assimilated to a retardance factor and must only be considered as a parameter for an empirical adjustment of the Equation (2).

Overall, the fit between observed LTs and those derived from the modified Izzard equation was quite good, with points distributed in similar proportions in the over- and underestimation zone (Fig. 7). Bentancor et al. (2014) obtained an $r^{2}=0.56$ between observed and calculated values with the modified Izzard method, including the precipitation intensity.

\section{Precipitation as a predictor}

One contribution of this paper is its emphasis on lagtime's dependence upon precipitation characteristics. This changes the notion that each watershed has a fixed LT (i.e., a parameter), to the idea that LT is a factor that can vary in time as a function of rainfall duration (i.e., a variable). LTs can be represented as a frequency distribution that can be associated with a probability density function, which converts LT into a random variable in statistical terms. Of course, LT is a function of rainfall duration, in addition to other factors, but this variable can, in turn, be the consequence of meteorological phenomena whose analysis is beyond the scope of this paper. Regardless, this poses a challenge in hydrological modelling: how can a random variable be incorporated into calculations of maximum discharge associated with a given watershed? This is an issue that does not occur when Tc or LT are considered as single, fixed values.

\section{Scope of applicability}

It would be naive to assume that the equations with the best performance in this study would also work well in any possible setting. Clearly, the empirical, semiempirical and physically based methods found in the literature adequately explain the LTs or Tcs in the specific environments where the equations were developed. Moreover, they should work well in regions similar to the original scope of the model's calibration, for example, among semiarid regions (Sharifi and Hosseini, 2011). Consequently, our findings could be applied to areas with similar conditions to those found in the southern regions of Chile, which have a rainy, temperate climate, with most of the precipitation concentrated in the winter. Moreover, dense tree/herb cover, soil type, and geomorphological characteristics, such as extensive floodplains, should also be considered.

We were unable to find another critical evaluation regarding which methods have the best performance in this country; therefore, our results could be applied to improve the official technical handbooks concerning the design of hydraulic works. DGA (1995) includes the use of design hydrographs for different Chilean macrozones, but the zoning is not sufficient and must be further developed. We recommend carrying out a better characterization of LT or Tc considering the specific characteristics of each watershed, along with its unique plant cover and rainfall attributes.

We further recommend a direct determination of LT or Tc by means of hyetograph-hydrograph analyses to define which method functions best in a given region. This method could then be applied with confidence to other similar, unmonitored catchments. In our study, Izzard's modified equation proved to be the best estimator of observed LTs and could therefore be used for predicting this variable in specific rain events with known rainfall durations. This variable is easy to determine and can be measured in a location not necessarily adjacent to the watershed of interest, as in this study. Of course, we could use the relationship LT/rainfall duration shown in Fig. 5c without considering the Izzard formula, but we would lose the opportunity to make some adjustments related to slope and main channel length that are included within Izzard's formulation.

\section{CONCLUSIONS}

We found that lagtimes (and times of concentrations) were rather long in the main watershed studied, possibly due to the extensive flat zones within the floodplains, and the retardance imposed by dense herb and tree vegetation. Only methods that included precipitation or stream velocity as predictors agreed reasonably well with observed lagtimes. They were both temporally and spatially variable, according to the rainfall duration and the point of watershed where evaluations were carried out, respectively. Izzard's modified method showed the best fit with observed data, and the velocity method proved promising if more field data were available to account for varying LTs within and across the seasons. In spite of the fact that our suggested equations can be locally applied, our procedure has heuristic value as it stresses the recommendation that lagtimes and times of concentration must be locally determined with rainfalldischarge analyses, in addition to explicitly considering precipitation patterns.

Acknowledgements. Funding was provided by the Fondecyt grant 1110156. INIA hosted the first author during the phase of data collection. We would like to thank the Estación Experimental Agropecuaria Austral staff for their help, especially the Administrator Carlos Villagra. Logistical support was provided by Mr. César Lemus, Mlle. Mélanie Krauth, and Rodrigo Bravo. Additional acknowledgements go to Dr. Carlos Oyarzún (Universidad Austral de Chile) and Dr. Christian Little (INFOR) who supported this research, Drs. Antonio Lara and Mr. David Lobos from $\mathrm{CR}^{2}$ (Center for Climate and Resilience Research) for lending us part of the equipment used in this study, and to the Water Center CRHIAM Conicyt/Fondap/15130015 for supporting part of the data analysis in addition to the English edition of the document. Finally, two anonymous reviewers contributed with helpful suggestions.

\section{REFERENCES}

ADOT (Arizona Department of Transportation), 1993. Highway Drainage Design Manual Hydrology. Phoenix, USA, 336 p.

Amigo, J., Ramírez, C., 1998. A bioclimatic classification of Chile: woodland communities in the temperate zone. Plant Ecol., 136, 1, 9-26.

Argente-Sanz, J.C., 2014. Estudio del comportamiento hídrico de una cuenca hidrológica en Angola. Trabajo Fin de Grado Ingeniería en Geomática y Topografía. Escuela Técnica Superior de Ingeniería Geodésica, Cartográfica y Topográfica, Universidad Politécnica de Valencia, Valencia, España, 61 p.

Bentancor, L., Silveira, L., García-Petillo, M., 2014. Incidencia de la intensidad de lluvia en el tiempo de concentración de microcuencas del Uruguay. Agrociencia-Uruguay, 18, 2, 106-116.

Bransby-Williams, G., 1922. Flood discharge and the dimensions of spillways in India. The Engineer (London), 121, 321-322.

CDH (California Division of Highways), 1960. California culvert practice: reprint of a series of technical abstracts from Cali- 
fornia highways and public works. 2nd printing. State of California, Department of Public Works, Division of Highways, Sacramento, USA, $119 \mathrm{p}$.

Chow, V.T., 1959. Open-Channel Hydraulics. McGraw Hill, New York, USA, $680 \mathrm{p}$.

Chow, V.T., Maidment, V.R., Mays, L.W., 1988. Applied Hydrology. McGraw-Hill, New York, USA, 572 p.

CIREN (Centro de Información de Recursos Naturales), 2001. Estudio Agrológico X Región. Tomo I. CIREN, Santiago, Chile, $480 \mathrm{p}$.

CIREN (Centro de Información de Recursos Naturales), 2003. Descripciones de Suelos, Materiales y Símbolos. Estudio Agrológico X Región, Publicación 123. CIREN, Santiago, Chile.

Cuevas, J.G., Arumí, J.L., Zúñiga-Feest, A., Little, C., 2018. An unusual kind of diurnal streamflow variation. J. Hydrol. Hydromech., 66, 1, 32-42.

de Almeida, I.K., Almeida, A.K, Ayach-Anache, J.A., Steffen, J.L., Alves-Sobrinho, T., 2014. Estimation on time of concentration of overland flow in watersheds: a review. Geociências, 33, 4, 661-671.

de Almeida, I.K., Almeida, A.K., Garcia-Gabas, S., Alves-Sobrinho, T., 2017. Performance of methods for estimating the time of concentration in a watershed of a tropical region. Hydrolog. Sci. J., 62, 14, 2406-2414. DOI: 10.1080/02626667.2017.1384549.

DGA (Dirección General de Aguas), 1995. Manual de Cálculo de Crecidas y Caudales Mínimos en Cuencas sin Información Fluviométrica. Dirección General de Aguas, Ministerio de Obras Públicas, Santiago, Chile, 88 p. Available at: http://documentos.dga.cl/FLU398.pdf [Accessed 04 Nov. 2017].

Dörner, J., Dec, D., Zúñiga, F., Horn, R., López, I., Leiva, C., Cuevas, J., 2013. Soil changes in the physical quality of an andosol under different management intensities in Southern Chile. In: Krümmelbein, J., Horn, R., Pagliai, M. (Eds.): Soil Degradation. Adv. Geoecol., 42, 262-281.

Dörner, J., Huertas, J., Cuevas, J.G., Leiva, C., Paulino, L., Arumí, J.L., 2015. Water content dynamics in a volcanic ash soil slope in southern Chile. J. Plant Nutr. Soil Sci., 178, 4, 693-702.

Edwards, R.T., 1998. The hyporheic zone. In: Naiman, R.J., Bilby, R.E. (Eds.): River Ecology and Management, Lessons from the Pacific Coastal Ecoregion. Springer, New York, USA, Chapter 16, pp. 399-429.

Folmar, N.D., Miller, A.C., 2008. Development of an empirical lag time equation. J. Irrig. Drain. E. ASCE, 134, 4, 501-506.

Giandotti, M., 1940. Previsione empirica delle piene in base alle precipitazioni meteoriche, alle caratteristiche fisiche e morfologiche dei bacini; Applicazione del metodo ad alcuni bacini dell'Appennino Ligure. Memorie e Studi Idrografici, 10, 5-13. Available at: http://hydrologie.org/redbooks/ a025/Potam Q2 R1 [Accessed 04 Nov. 2017].

Granato, G.E., 2012. Estimating Basin Lagtime and HydrographTiming Indexes Used to Characterize Stormflows for RunoffQuality Analysis. Scientific Investigations Report 2012-5110. U.S. Department of the Interior, U.S. Geological Survey, Reston, Virginia, USA, 58 p. Available at: https://pubs.usgs.gov/sir/2012/5110/pdf/sir2012-5110_text.pdf [Accessed 04 Nov. 2017].

Gumbel, E.J., 1960. Multivariate extremal distributions. Bull. Inst. Internat. de Statistique 37, 471-475.

Izzard, C.F., 1946. Hydraulics of runoff from developed surfaces. In: Proc. 26th Annual Meeting of the Highway Research Board. Highway Research Board, Washington, USA, pp. 129-146.

Kerby, W.S., 1959. Time of concentration for overland flow. J. Civil Eng., ASCE, 26, 3, 60-68.

Kirpich, Z.P., 1940. Time of concentration of small agricultural watersheds. Civil Eng., 10, 6, 362-368.

Mata-Lima, H., Vargas, H., Carvalho, J., Gonçalves, M., Caetano, H., Marques, A., Raminhos, C., 2007. Comportamento hidrológico de bacias hidrográficas: integração de métodos e aplicação a um estudo de caso. Rem-Rev. Esc. Minas, 60, 3,
$525-536$.

McCuen, R.H., 2009. Uncertainty analyses of watershed time parameters. J. Hydrol. Eng., 14, 5, 490-498. DOI: 10.1061/(ASCE)HE.1943-5584.0000011\#sthash. qleAhfH8.dpuf

McCuen, R.H., Spiess, J.M., 1995. Assessment of kinematic wave time of concentration. J. Hydraul. Eng. ASCE, 121, 3, 256-266.

McCuen, R.H., Wong, S.L., Rawls, W.J., 1984. Estimating urban time of concentration. J. Hydraul. Eng., 110, 7, 887-904.

Morgali, J.R., Linsley, R.K., 1965. Computer analysis of overland flow. J. Hydraul. Div., 95, 81-100.

NRCS (Natural Resource Conservation Service), 1986. Urban Hydrology for Small Watersheds. Technical Release 55. U.S. Department of Agriculture, Washington, DC, USA, $164 \mathrm{p}$. Available at: https://www.nrcs.usda.gov/Internet/ FSE DOC UMENTS/stelprdb1044171.pdf [Accessed 04 Nov. 2017].

Papadakis, C., Kazan, N., 1986. Time of Concentration in Small Rural Watersheds. Technical report 101/08/86/CEE. College of Engineering, University of Cincinnati, Cincinnati, USA, $18 \mathrm{p}$.

Pasini, F., 1914. Relazione sul progettodella bonifica renana, Bologna, Italy.

Sharifi, S., Hosseini, S.M., 2011. Methodology for identifying the best equations for estimating the time of concentration of watersheds in a particular region. J. Irrig. Drain. E. ASCE, 137, $11,712-719$.

Sheridan, J.M., 1994. Hydrograph time parameters for flatland watersheds. Trans. of Am. Soc. Agr. Eng., 37, 1, 103-113.

Simas, M., 1996. Lag Time Characteristics in Small Watersheds in The United States. A dissertation submitted to School of Renewable Natural Resources, University of Arizona, Tucson, USA, $174 \mathrm{p}$

Singh, N., Singh, K.K., 2017. Geomorphological analysis and prioritization of sub-watersheds using Snyder's synthetic unit hydrograph method. Appl. Water Sci., 7, 1, 275-283. https://doi.org/10.1007/s13201-014-0243-1

Soil Survey Staff, 1999. Soil taxonomy: A Basic System of Soil Classification For Making and Interpreting Soil Surveys. 2nd edition. Natural Resources Conservation Service, U.S. Department of Agriculture Handbook 436, Washington, DC, USA, $886 \mathrm{p}$.

Sokal, R.R., Rohlf, F.J., 1995. Biometry: The Principles and Practice of Statistics in Biological Research. Third edition. W. H. Freeman and Company, New York, USA, 885 p.

Témez, J.R., 1978. Cálculo hidrometeorológico de caudales máximos en pequeñas cuencas naturales. Ministerio de Obras Públicas y Urbanismo (MOPU), Dirección General de Carreteras, Madrid, España, 96 p.

Tucci, C., 2000. Hidrología, Ciência e aplicaçao. Coleção ABRH de Recursos Hídricos 4). Universidade Federal do Rio Grande do Sul, Porto Alegre, Brazil, 944 p.

USDA-NRCS (United States Department of Agriculture-Natural Resources Conservation Service), 2010. Chapter 15: Time of Concentration. In: USDA- NRCS (Ed.): National Engineering Handbook, Part 630 Hydrology. Washington, DC, pp. 15i-15B-3.

Vélez, J.J., Botero, A., 2011. Estimation of the time of concentration and the lag time at San Luis Creek basin, Manizales. Dyna, 78, 165, 58-71. (In Spanish.)

Wondzell, S.M., Gooseff, M.N., McGlynn, B.L., 2007. Flow velocity and the hydrologic behavior of streams during baseflow. Geophys. Res. Lett., 34, L24404. DOI: 10.1029/2007g1031256.

WRB, 2006. World Reference Base for Soil Resources. A Framework for International Classification, Correlation and Communication. 2nd Edition. FAO, World Soil Resources Reports, 103, Rome, Italy, $142 \mathrm{p}$.

Received 15 November 2017 Accepted 23 May 2018 
Appendix 1. Selected formulae to calculate times of concentration or lagtimes. Formulae were chosen to show the diversity of approaches. Other methods can be found in the references included in Table 3.

\begin{tabular}{|c|c|c|c|}
\hline $\begin{array}{l}\text { Equation } \\
\text { number }\end{array}$ & Method & Formula & Units $^{\mathrm{a}}$ \\
\hline A1 & Kerby (1959) & $T c=\left[\frac{2.2 n L}{Y^{0.5}}\right]^{0.324}$ & $\begin{array}{c}\mathrm{Tc}(\min ), \mathrm{n}\left(\mathrm{m}^{-1 / 3} \mathrm{~s}\right), \mathrm{L}(\mathrm{ft}) \\
\mathrm{Y}(\mathrm{ft} / \mathrm{ft})\end{array}$ \\
\hline A2 & $\begin{array}{l}\text { California Division of High- } \\
\text { ways (1960) }\end{array}$ & $T c=0.95\left[\frac{L^{3}}{H}\right]^{0.385}$ & Tc (h), L (km), H (m) \\
\hline A3 & Kirpich (1940) & $T c=\frac{0.02 L^{0.77}}{S^{0.385}}$ & Tc (min), L (m), S (m/m) \\
\hline A4 & $\begin{array}{l}\text { Soil Conservation Service: } \\
\text { Texas (USDA-NRCS, 2010) }\end{array}$ & $T c=2.4 A^{0.6}$ & Tc (h), A (squared miles) \\
\hline A5 & Simas II (1996) & $T c=\frac{0.0085 W^{0.5937} S_{\text {nat }}^{0.3131}}{Y^{0.1505}}$ & Tc (h), W (ft), $S_{\text {nat }}($ in $), Y(f t / f t)$ \\
\hline A6 & Bransby-Williams (1922) & $T c=\frac{L}{1.5 D c} \sqrt[5]{\frac{A^{2}}{S}}$ & $\begin{array}{l}\text { Tc }(\mathrm{h}), \mathrm{L}(\mathrm{km}), \mathrm{A}\left(\mathrm{km}^{2}\right) \\
\operatorname{Dc}\left(\mathrm{km}^{2}\right), \mathrm{S}(\%)\end{array}$ \\
\hline A7 & Granato (2012) RE07 & $L T=1.272 * 0.760 B L F^{0.571} *(13-B D F)^{0.681}$ & $\begin{array}{l}\left.\text { LT (h), BLF (mile }{ }^{1.5} \mathrm{ft}^{-0.5}\right) \\
\operatorname{BDF}(-)\end{array}$ \\
\hline A8 & Granato (2012) RE06 & $L T=1.360 * 0.514 B L F^{0.565} *(100-0.99 I M P E R V)^{0.394}$ & $\begin{array}{c}\left.\text { LT (h), BLF (mile }{ }^{1.5} \mathrm{ft}^{-0.5}\right) \\
\text { IMPERV (\%) }\end{array}$ \\
\hline A9 & Papadakis and Kazan (1986) & $T c=\frac{0.66 L^{0.5} n^{0.52}}{S^{0.31} i^{0.38}}$ & $\begin{array}{l}\text { Tc (min), } \mathrm{L}(\mathrm{ft}), \mathrm{n}\left(\mathrm{m}^{-1 / 3} \mathrm{~s}\right) \\
\mathrm{S}(\mathrm{ft} / \mathrm{ft}), \mathrm{i}(\mathrm{in} / \mathrm{h})\end{array}$ \\
\hline A10 & Morgali and Linsley (1965) & $T c=\frac{441 L^{0.6} n^{0.6}}{i^{0.4} Y^{0.3}}$ & $\begin{array}{l}\text { Tc (min), L }(\mathrm{km}), \mathrm{n}_{\left(\mathrm{m}^{-1 / 3} \mathrm{~s}\right), \mathrm{i}} \\
(\mathrm{mm} / \mathrm{h}), \mathrm{Y}(\mathrm{m} / \mathrm{m})\end{array}$ \\
\hline A11 & Izzard (1946) & $T c=\frac{526.42\left(0.0000276 i+c_{r}\right) L^{1 / 3}}{S^{1 / 3} i^{2 / 3}}$ & $\begin{array}{l}\text { Tc }(\min ), i(\mathrm{~mm} / \mathrm{h}), \mathrm{c}_{\mathrm{r}}(-) \\
\mathrm{L}(\mathrm{m}), \mathrm{S}(\mathrm{m} / \mathrm{m})\end{array}$ \\
\hline
\end{tabular}

\begin{abstract}
a Abbreviations: $\mathrm{A}=$ watershed area; BDF is the basin development factor, defined as an index of urbanization and the prevalence of engineered drainage features (see Granato, 2012 for further details); BLF is the basin length in miles divided by the square root of the channel slope (ft/mile); $\mathrm{c}_{\mathrm{r}}=$ retardance factor; $\mathrm{Dc}=$ diameter of the circle with an area equivalent to the watershed area; $\mathrm{H}=$ difference in watershed elevation from headwaters to outlet; IMPERV $=$ the percentage of impervious area in the watershed (roofs, highways, etc.); $i=$ intensity of the rainfall excess; $\mathrm{L}=$ length of channel from headwater to outlet; $\mathrm{LT}=$ lagtime; $n=$ Manning's channel roughness coefficient; $\mathrm{S}=$ mean channel slope; $S_{\text {nat }}=$ storage coefficient used in the curve number method calculated as $S_{\text {nat }}=(1000 / C N)-10$, where $C N$ is the runoff curve number; $\mathrm{Tc}=$ time of concentration; $\mathrm{W}=$ watershed width $\left(\right.$ area $\left(\mathrm{ft}^{2}\right) /$ watershed length $\left.(\mathrm{ft})\right) ; \mathrm{Y}=$ average watershed slope.
\end{abstract}

Appendix 2. Detailed description of the velocity method (NRCS, 1986)

The velocity method calculates the stream velocity for three segments selected along the main channel length, based on homogeneity. Travel time is obtained by dividing the segment length by the respective velocity. In the headwaters, three types of flow can be evaluated: sheet flow, shallow concentrated flow, and open channel flow. In the lower segments, only open channel flow is estimated.

The sheet flow is calculated from:

$T t=\frac{0.007(n \ell)^{0.8}}{\left(P_{2}\right)^{0.5} S_{h}^{0.4}}$

where $T t$ is the partial travel time (h), $n$ is the Manning's roughness coefficient for sheet flow, $\ell$ is the sheet flow length ( $\mathrm{ft}$ ), $\mathrm{P}_{2}$ is the 2-year, 24-hour rainfall (inches), and $\mathrm{S}_{\mathrm{h}}$ is the slope of land surface in that segment $(\mathrm{ft} / \mathrm{ft})$.
McCuen and Spies (1995) proposed improving the $\ell$ estimation (considered as default as $100 \mathrm{ft}$ ), by means of:

$$
\ell=\frac{100 \sqrt{S_{h}}}{n}
$$

where the symbols were previously defined.

The shallow concentrated flow has the general formula: $V=$ $\mathrm{k}^{*}(\mathrm{~S})^{0.5}$, where $\mathrm{V}$ is the water velocity $(\mathrm{ft} / \mathrm{s})$, and can be obtained from Fig. 15-4 in USDA-NRCS (2010).

The open channel flow is calculated using Manning's equation:

$V=\frac{1.49 r^{2 / 3} S^{1 / 2}}{n}$

$r$ is the hydraulic radius ( $\mathrm{ft}$ ) calculated as $\mathbf{a} / \mathrm{Pw}$, where $\mathbf{a}$ is the cross-sectional flow area $\left(\mathrm{ft}^{2}\right), \mathrm{Pw}$ is the wetted perimeter $(\mathrm{ft})$, the channel slope (S) is in $\mathrm{ft} / \mathrm{ft}$, and $n$, in this case, is the Manning's $n$ value for open channel flow (Chow, 1959). 